\title{
NEW RECORD OF LIPOPTENA MAZAMAE RONDANI, 1878 AS A MAZAMA GOUAZOUBIRA (FISCHER, 1814) PARASITE IN SOUTHERN BRAZIL
}

\section{NOVO REGISTRO DE LIPOPTENA MAZAMAE RODANI, 1878 COMO PARASITO DE MAZAMA GOUAZOUBIRA (FISCHER, 1814) NO SUL DO BRASIL}

\author{
Emili Bortolon dos Santos \\ Diego Duarte Varela ${ }^{2}$ \\ Bruna Guedini Tizoni ${ }^{3}$ \\ Alexandre de Oliveira Tavela ${ }^{4}$
}

Submetido: 20/06/2020 / Aceito: 30/04/2021 / Publicado: 31/10/2021.

\begin{abstract}
Resumo
Moscas da família Hipoboscidae (Lipoptena mazamae) são parasitos muito importantes do veadocatingueiro (Mazama gouazoubira), podendo ser encontrados em uma considerável abundância nesse mamífero. Sua distribuição é conhecida em apenas alguns locais, como em algumas cidades do estado do Rio Grande do sul, e, por causa disso, é muito importante reportar novos registros dessa associação de parasitismo. Para contribuir com o conhecimento dessa associação, é reportado aqui um novo registro dessa mosca parasitando um indivíduo de veado-catingueiro na cidade de Curitibanos, estado de Santa Catarina, sul do Brasil. Esses registros se destacam, pois $L$. mazamae possui importância médica e veterinária, devido ao seu potencial de veicular agentes etiológicos causadores de doenças, como bartonelose. Além disso, depois de nossas pesquisas, concluímos que este é apenas o quinto estudo reportando essa associação na América do Sul, indicando, portanto, sua relevância. Estudos como este são importantes, pois contribuem com novos registros dessa associação de parasitismo, e, portanto, pode-se também servir como alerta às autoridades para a possível associação desses parasitos com doenças que podem causar danos à saúde humana e de outros animais.
\end{abstract}

Palavras-chave: Moscas, parasitos, Santa Catarina, veado-catingueiro.

\begin{abstract}
Louse flies (Lipoptena mazamae) are important Gray brocket deer (Mazama gouazoubira) parasites, and can be found in large numbers in this mammal. Their distribution is known for just a few locations, such as in a few municipalities of the state of Rio Grande do Sul, and because of this, it is so important to report new records of this association. To contribute with knowledge concerning this parasitism relationship, a record of this fly species parasitizing a deer individual in

\footnotetext{
${ }^{1}$ MSc. Federal University of Santa Catarina, UFSC, Campus Trindade, Centro de Ciências Biológicas, Florianópolis, state of Santa Catarina; emili.bsantos@gmail.com

${ }^{2}$ Master Student. Federal University of Santa Catarina, UFSC, Campus Curitibanos, Centro de Ciências Biológicas, Curitibanos, state of Santa Catarina; diegoduartevarela@gmail.com

3 Master Student. University of São Paulo, USP, Departamento de Cirurgia Veterinária, Faculdade de Medicina Veterinária e Zootecnia, São Paulo, state of São Paulo; brunatizoniguedine@gmail.com

${ }^{4}$ Ph.D. Federal University of Santa Catarina, UFSC, Campus Curitibanos, Centro de Ciências Biológicas, Curitibanos, state of Santa Catarina; alexandre.tavela@ufsc.br
} 
the municipality of Curitibanos, state of Santa Catarina, southern Brazil, is reported herein. Such records are paramount, as L. mazamae displays both zoonotic and medical importance, due to the potential propagation of etiological agents that cause diseases, such as Bartollenosis. Moreover, as far as we know, this study is only the fifth study that reports this association in South America, indicating its relevance. It is very important to perform studies as these, because we may contribute to new records of this association of parasitism, therefore, we contribute to alert authorities to the possible association of these parasites with diseases that may pose problems for human and other animal health.

Keywords: Gray brockets, Louse flies, Parasites, Santa Catarina state.

\section{INTRODUÇÃO}

Lipoptena mazamae Rondani, 1878 are commonly known as Louse flies or deer keds, and belong to the Hippoboscidae family (Diptera order). This species is distributed throughout several countries in the American continent, and, in Brazil, has been reported in the states of Amazonas, Pará, Mato Grosso, São Paulo, Paraná, Santa Catarina and Rio Grande do Sul (GRACIOLLI and CARVALHO, 2003). In the state of Santa Catarina, L. mazamae was recorded for the first time in 2008, parasitizing a Mazama gouazoubira (Fischer, 1814) (Gray brocket) specimen, in the municipality of Lages, by Marques et al. (2009).

Members belonging to the Lipoptena genus feed on blood and parasite of both mammals and birds, including deer from the family Cervidae. In this regard, both Odocoileus virginianus (Zimmermann, 1780) and M. gouazoubira have been recorded as hosts (e.g. SAMUEL and TRAINER, 1972; RIBEIRO et al., 2003). Normally this parasitic genus tends to scarify and bite around the neck and posterior region of their hosts, causing significant blood and weight loss and, when present in high parasitic loads, may predispose the animals to secondary infections by other agents, leading to death. This parasitic genus has also been considered an Anaplasma spp. carrier in cattle and Trypanosoma spp. in cervids (BÖSE and PETERSEN, 1991; GARCIA et al., 2020).

In addition, L. mazamae has been reported as infected with Bartonella spp. in Southern Brazil and other areas (e.g. SOUZA et al., 2017). This is a Gram-negative bacterium that infects certain cells, such as erythrocytes, causing the disease known as Bartonellosis, which evolves to cause a long-lasting, relapsing, and intraerythrocytic bacteremia (BREITSCHWERDT, 2014). The fact that L. mazamae may be infected by Bartonella species is of increasing concern, as several animal species may act as reservoirs, including rodents, ground squirrels and both insectivorous and frugivorous bats. This indicates that Bartonellosis may be a disease displaying zoonotic importance, which may endanger human lives (e.g. MÜHLDORFER, 2013). Hence, assessments on this host-parasite association are paramount, as (1) knowledge concerning the distribution of both species in this relation of parasitism is still scarce, thus emphasizing basic science; and (2) local and even national authorities may be alerted in relation to another record of parasites exhibiting public health importance, since they may transmit etiological agents that display the potential to cause both human and other animal diseases.

Therefore, the aims of the present study comprise reporting a dipteran species parasitizing a brocket (M. gouazoubira), perform a compilation of previous records of this parasitic relationship worldwide and, finally, to comment on the importance of this parasitic relationship between insects and vertebrates regarding public health. 


\section{MATERIAL AND METHODS}

An adult female M. gouazoubira was received by the Anatomy Laboratory belonging to the Federal University of Santa Catarina (UFSC), located in the municipality of Curitibanos, in the state of Santa Catarina, southern Brazil, on February $8^{\text {th }}, 2018$. The deer was found on the banks of the BR-470 Highway between the municipalities of Curitibanos and Frei Rogério, and was integrated into the laboratory collection for further studies. The presence of louse flies L. mazamae ectoparasites on the Gray brocket was noted, comprising 56 adult individuals distributed in the deer's neck, auricular pavilion and gluteal regions. The flies were stored and forwarded to the Laboratory of Parasitic Animal Diseases (LaDoPA - UFSC) for standard taxonomic classification and for their maintenance in its zoological collection as well (Figure 1).

Figure 1. Lipoptena mazamae. A- Dorsal surface. B- Ventral surface.

\section{RESULTS AND DISCUSSION}

The deer health conditions are unclear, and health problems due to the parasitic flies or transmitted pathogens by these flies were not assessed. Investigations of live or necropsied animals are paramount to determine and obtain information on the distribution of parasitic hosts, leading to understanding of their pathogenicity and seasonality patterns.

Unfortunately, the animal was found run over on the banks of a highway, which is very common in Brazil. Wild animal roadkill represents an important record of local loss of biodiversity, and may result in significant declines in the populations of many species (TUMELEIRO et al., 2006; OLIVEIRA and SILVA, 2012). Many measures are proposed to avoid accidents, such as the construction of underpasses and overpasses, fences and speed reducers (GRILO et al., 2010). However, in a study on roadkill animals conducted in western Santa Catarina, none of these measures were found on routes used to verify the number of dead animals on roads (ORLANDIN et al., 2015).

Very few records of L. mazamae parasitizing M. gouazoubira are available, both for Brazil and worldwide, and only four articles reporting this parasitic relationship were found in a literature search (RIBEIRO et al., 2003; DEEM et al., 2004; MARQUES et al., 2009; SOUZA et al., 2017), one from Gran Chaco, Bolivia (DEEM et al., 2004) (Table 1). On the other hand, several records of L. mazamae as parasites in other mammals, such as $O$. virginianus (white-tailed deer) (BEQUAERT, 1956; SAMUEL and TRAINER, 1972; GARCIA et al., 2020) and cattle (EADS, 1949; DRUMMOND, 1966) have been reported.

Table 1. Records of L. mazamae as M. gouazoubira parasites worldwide.

The present study is relevant, as few studies concerning parasite records for $M$. gouazoubira are available. In addition to contributing to further knowledge on this relationship, these types of assessments are relevant to serve as warnings, as L. mazamae may be infected with certain pathogens, i.e. the bacterium Bartonella (e.g. SOUZA et al., 2017). Bartollenosis caused by this bacterium is of zoonotic importance, and is of concern to human health. Therefore, more reports and information are required to determine the main parasitic agents found in L. mazamae, the geographical distribution of the insect parasitizing Gray brocket deer, and its distribution throughout Brazil. 


\section{REFERÊNCIAS}

BEQUAERT JC. The Hippoboscidae or louseflies (Diptera) on mammals and birds. Part II. Taxonomy, evolution and revision and American genera and species (continued from volume XXXV). Entomologica Americana, v. 36, p. 417-611, 1956.

BÖSE R, PETERSEN K. Lipoptena cervi (Diptera), a potential vector of Megatrypanum trypanosomes of deer (Cervidae). Parasitology Research, v. 77, n. 8, p. 723-725, 1991.

BREITSCHWERDT EB. Bartonellosis: One health perspectives for an emerging infectious disease. ILAR Journal, v. 55, n. 1, p. 46-58, 2014.

EADS RB. A second record of Lipoptena mazamae from cattle. Journal of Economical Entomology, v. 42, n. 1, p. 158, 1949.

DRUMMOND RO. Lipoptena mazamae Rondani (Diptera: Hippoboscidae), a louse fly of deer, on cattle in southwestern Texas. Journal of Parasitology, v. 52, n. 4, p. 525, 1966.

GARCIA HA, BLANCO PA, RODRIGUES AC, RODRIGUES CMF, TAKATA CSA, CAMPANER M, CAMARGO EP, TEIXEIRA MA. Pan-American Trypanosoma (Megatrypanum) perronei sp. $\mathrm{n}$. in white-tailed deer (Odocoileus virginianus) and its deer ked Lipoptena mazamae: morphological, developmental and phylogeographical characterization. Parasites \& Vectors, v. 13, p. 308, 2020

GRACIOLLI G, CARVALHO CJ. Hippoboscidae (Diptera, Hippoboscoidea) no estado do Paraná, Brasil: chaves de identificação, hospedeiros e distribuição geográfica. Revista Brasileira de Zoologia, v. 20, n. 4, p. 667-674, 2003.

GRILO C, BISSONETTE JA, CRAMER PC. Mitigation measures to reduce impacts on biodiversity. In: COLUMBUS, F. Highways: Construction, Management and Maintenance. New York: Nova Science Publishers, 2010. pp. 73-114.

MARQUES SMT, QUADROS RM, BENEDET R, MAZZOLLI M. First record of Lipoptena mazamae (Diptera: Hippoboscidae) in Mazama gouazoubira in Santa Catarina, Brazil. Biociências, v. 17, n. 1, p. 107-108, 2009.

MÜHLDORFER K. Bats and bacterial pathogens: a review. Zoonoses and Public Health, v. 60, n. 1, p. 93-103, 2013.

OLIVEIRA DS, SILVA VM. Vertebrados silvestres atropelados na BR158, RS, Brasil. Biotemas, v. 25, n. 4, p. 229-235, 2012.

ORLANDIN E, PIOVESAN M, FAVRETTO MA, D'AGOSTINI FM. Mamíferos de médio e grande porte atropelados no Oeste de Santa Catarina, Brasil. Biota Amazônia, v. 5, n. 4, p. 125130, 2015. 
RIBEIRO PB, BICHO CL, VIANNA EES, COSTA PRP. Lipoptena (Lipoptenella) mazamae Rondani, 1878 (Diptera: Hippoboscidae) em Mazama gouazoubira (Fischer, 1814) (VeadoCatingueiro), no Rio Grande do Sul, Brasil. Arquivos do Instituto Biológico, v. 70, n. 2, p. 211, 2003.

SAMAUEL WM, TRAINER DO. Lipoptena mazamae Rondani, 1878 (Diptera: Hippoboscidae) on White-tailed deer in Southern Texas. Journal of Medical Entomology, v. 9, n. 1, p. 104-106, 1972.

SOUZA U, DALL'AGNOL B, MICHEL T, WEBSTER A, KLAFKE G, MARTINS JR, KASPER CB, TRIGO TC, OTT R, JARDIM MMA, RECK J. Detection of Bartonella sp. in deer louse flies (Lipoptena mazamae) on Gray brocket deer (Mazama gouazoubira) in the Neotropics. Journal of Zoo and Wildlife Medicine, v. 48, n. 2, p. 532-535, 2017.

TUMELEIRO LK, KOENEMANN J, ÁVILA CNM, PANDOLFO FR, OLIVEIRA EV. Notas sobre mamíferos da região de Uruguaiana: Estudo de indivíduos atropelados com informações sobre a dieta e conservação. Biodiversidade Pampeana, v. 4, n. 2, p. 38-41, 2017. 
Figure 1.

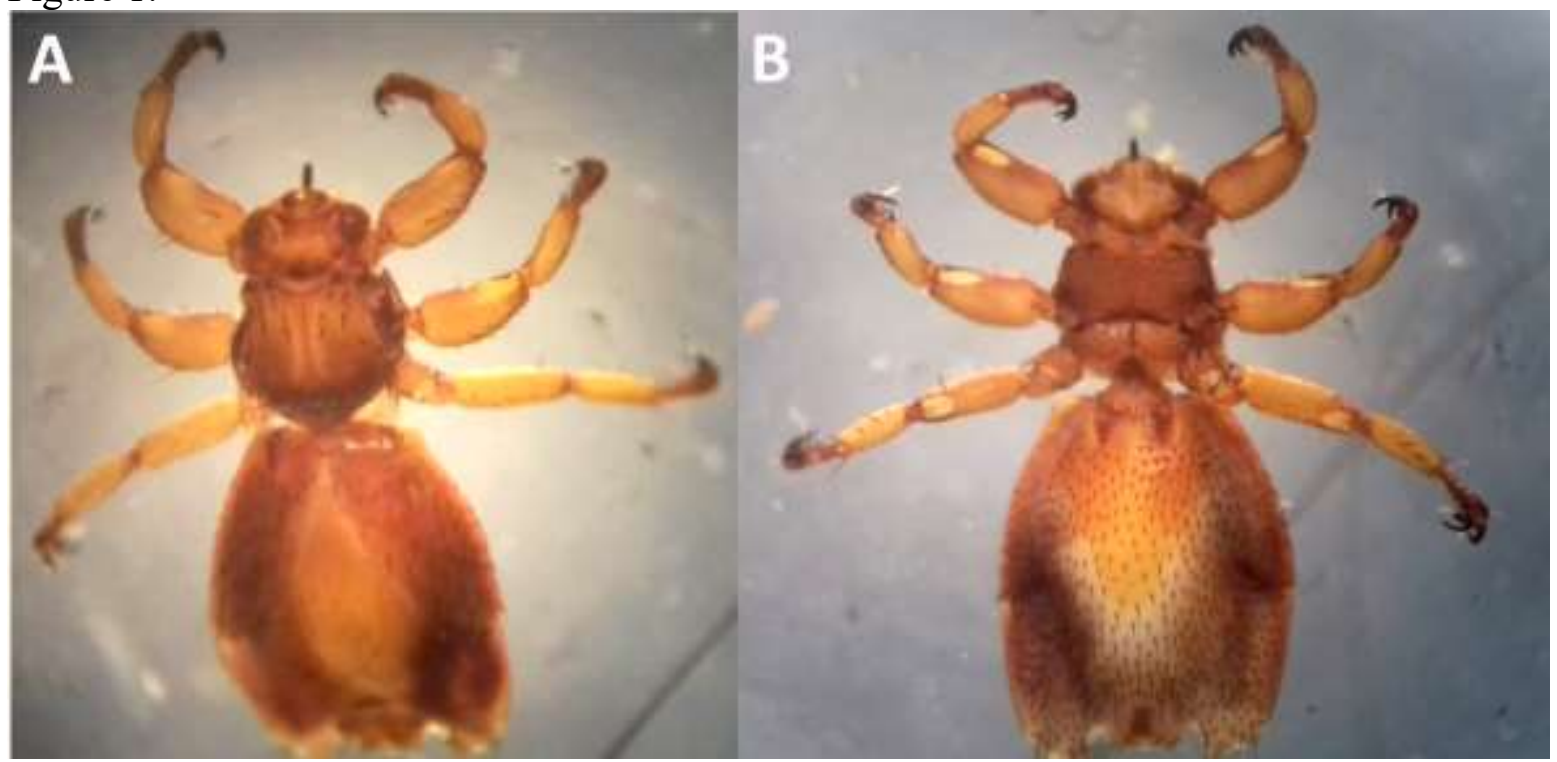

Table 1.

\begin{tabular}{lccc}
\hline Ectoparasite & Host & Site & Reference \\
\hline L. mazamae & M. gouazoubira & Herval do Sul and São Francisco de Paula & Ribeiro et al. (2003) \\
L. mazamae & M. gouazoubira & Lages (Santa Catarina state, Brazil) & Marques et al. (2009) \\
& Caçapava do Sul, São Sepé, São Jerônimo, & \\
M. mazamae & Arroio dos Ratos, Bagé, Hulha Negra, & Souza et al. (2017) \\
& M. gouazoubira & Santana do Livramento, and Maquiné (Rio & \\
L. mazamae & Grande do Sul state, Brazil) & Deem et al. (2004) \\
\hline
\end{tabular}

